\title{
SECONDARY METABOLITES FROM THE CULTURE BROTH OF ACTINOMYCETE ACROCARPOSPORA SP. FIRDI 001 AND THEIR ANTIMICROBIAL ACTIVITY
}

\author{
MING-JEN CHENG ${ }^{1}$, MIN TSENG ${ }^{*}$, IH-SHENG CHEN ${ }^{2}$, CHII-CHERNG LIAO' AND GWO-FANG YUAN ${ }^{\text {* }}$ \\ ${ }^{1}$ Bioresource Collection and Research Center (BCRC), Food Industry Research and Development Institute (FIRDI), Hsinchu 300, Taiwan. \\ ${ }^{2}$ Graduate Institute of Natural Products, College of Pharmacy, Kaohsiung Medical University, Kaohsiung 807, Taiwan.
}

(Received: January 20, 2009 - Accepted: May 29, 2009)

\begin{abstract}
Two natural new compounds, pyrroline-2-one (1) and 2-(2-amino-3-methyl-butyrylamino)-3-(4-hydroxy-phenyl)-propionic acid (2), together with nine known compounds, iodinin (3), thymine (4), $N$-(2-hydroxy-phenyl)-acetamide (5), (Z)-pulchellalactam (6), uracil (7), nicotinic acid (8), nicotiamide (9); $p$-nitrophenol (10) and indole 3-carboxylic acid (11), all were isolated from the EtOAc extract of the culture broth of a new actinomycete Acrocarpospora sp. strain, FIRDI 001. The structures were elucidated by 1D and 2D NMR spectroscopy and mass spectrometry. Furthermore, the isolated compounds were subjected to evaluate the antimicrobial activity. Compounds $\mathbf{2 , 3}$ and $\mathbf{1 0}$ showed antimicrobial activity. The active metabolite, iodinin existed as a major metabolite in this study.
\end{abstract}

Keywords: Acrocarpospora sp., Actinomycetes, Secondary metabolites, alkaloids, Iodinin, Antimicrobial activity.

\section{INTRODUCTION}

Microorganisms that can survive in diverse environments are of great interest for scientists. The actinomycetes, an order of filamentous bacteria, have proven to be a rich source of secondary metabolites that might be useful for the development of new pharmaceutical agents ${ }^{1}$ and, in particular, Streptomyces species $^{2}$. In exploring the actinomycetes, we recently isolated a novel strain, FIRDI 001, from the soil of Taitung County with a unique morphology. On the basis of phenotypic and genotypic data (16s rDNA sequence, data not shown), it is proposed the strain should be identified as an Acrocarpospora species. The genus Acrocarpospora described by Tamura et al originally ${ }^{3}$, contains of the following three species: A. corrugatum, A. macrocephala and A. pleiomorpha. In our series screening on the bioactive compounds produced by microorganisms, FIRDI 001 displayed antimicrobial activities in vitro. No previous metabolites study has been processed in the Acrocarpospora genus. In this study, EtOAc-soluble fraction of FIRDI 001 culture broth was investigating for its antimicrobial activity. Eleven compounds were identified in this fraction including two alkaloids ( $\mathbf{1}$ and $\mathbf{2}$ ), the first time isolated from natural sources, together with 9 known compounds (3-11). We herein report the isolation and the antimicrobial activity properties of these compounds.

\section{EXPERIMENTAL}

\section{General experimental procedures}

Melting points were determined with a YANACO micro-melting point apparatus and were uncorrected. IR spectra were taken on a Hitachi 26030 spectrophotometer. UV spectra were obtained on a JASCO UV-240 spectrophotometer. EIMS spectra were recorded on a VG Biotech Quattro 5022 spectrometer. HREIMS were recorded on a JEOL JMX-HX 110 mass spectrometer. ${ }^{1} \mathrm{H}$ NMR and ${ }^{13} \mathrm{C}$ NMR spectra were measured on a Varian Gemini 200, and Varian Unity Plus 400 spectrometers, and are given in parts per million $(\delta)$ downfield from internal TMS. Si gel 60 (Merck 70-230 mesh, 230-400 mesh) was used for column chromatography, and Si gel $60 \mathrm{~F}_{254}$ (Merck) for TLC.

\section{Producing organisms and fermentation}

The actinomycete, Acrocarpospora sp. FIRDI 001, was isolated from a soil sample collected from Taitung County, Taiwan, by using HV agar ${ }^{4}$, and was then incubated at $28^{\circ} \mathrm{C}$ for 4 weeks. The strain was maintained on oatmeal agar and the spores or mycelia suspension were harvest with $20 \%$ (v/v) glycerol and stored at $-20^{\circ} \mathrm{C}$.

A mature slant culture of strain FIRDI 001 was inoculated into a $500-\mathrm{ml}$ flask containing $100 \mathrm{ml}$ of the seed medium consisting of $0.4 \%$ glucose, $0.4 \%$ yeast extract, and $1 \%$ malt extract $(\mathrm{pH} 7.3)$. After growing at r.t. for $4 \mathrm{~d}$ on a rotary shaker $(200 \mathrm{rpm})$, the aliquots $(2 \mathrm{ml})$ of seed culture were transferred into a $500 \mathrm{ml}$ flask containing $200 \mathrm{ml}$ of production medium $(0.4 \%$ glucose, $0.4 \%$ yeast extract, $1 \%$ malt extract, and $\left.0.3 \% \mathrm{CaCO}_{3} ; \mathrm{pH} 7.3\right)$. After 14 days cultivation at r.t. on a rotary shaker $(200 \mathrm{rpm})$ the culture filtrate were obtained by filtering through filter paper.

\section{Extraction and separation of compounds}

The culture filtrate was repeatedly extracted with EtOAc. Evaporation of the solvent afforded a dark brown crude extract ( $3 \mathrm{~g})$, which was chromatographed on silica gel and eluted with $n$-hexane, and the polarity was gradually increased with EtOAc and $\mathrm{MeOH}$ to furnish 15 fractions (A-1 to A-15). Fr. A-3 (452 $\mathrm{mg}$ ) was washed with $\mathrm{MeOH}$ to give iodinin (3) $(101.5 \mathrm{mg})$. The washing $(83.67 \mathrm{mg})$ was purified by HPLC, eluting with $n$-hexane-EtOAc $(10: 1)$ to afford pyrroline-2-one (1) (1.2 mg), and $N$-(2-hydroxy-phenyl)-acetamide (5) (5.2 mg). Fraction A-6 (1.5 g) was subjected to Sephadex LH-20 and eluted with $\mathrm{MeOH} / \mathrm{H}_{2} \mathrm{O}$ to give 6 fractions (A-6-1 to A-6-6). Fraction A-6-3 (12.4 $\mathrm{mg}$ ) was purified by preparative-TLC to produce $(Z)$-pulchellalactam (6) $(1.3$ $\mathrm{mg})$. Fraction A-7 (402 mg) was subjected to Sephadex LH-20 and eluted with $\mathrm{MeOH}$ to give nicotinic acid (8) $(8.5 \mathrm{mg})$ and nicotiamide (9) $(1.3 \mathrm{mg})$. Fraction A-9 $(4.09 \mathrm{~g})$ was subjected to silica gel and eluted with $\mathrm{CHCl}_{3}$, and then enriched with EtOAc to give $p$-nitrophenol $(\mathbf{1 0})(8.3 \mathrm{mg})$, and indole 3-carboxylic acid (11) $(6.3 \mathrm{mg})$. Fraction A-10 (11.69 g) was subjected to silica gel chromatography and eluted with $\mathrm{CH}_{2} \mathrm{Cl}_{2}-\mathrm{MeOH}$ step gradients to give uracil (7) (2.7 mg). Fraction 11 (2.8 g) was subjected to Sephadex LH20, and eluted with $\mathrm{MeOH}$ to give 2-(2-amino-3-methyl-butyrylamino)-3-(4hydroxy-phenyl)-propionic acid (2) (3.4 mg). Fraction 14 (3.1 g) was subjected to Sephadex LH-20, and eluted with $\mathrm{MeOH}$ to give thymine (4) $(1.4 \mathrm{mg})$.

pyrroline-2-one (1): Colourless oil; IR $v_{\max }$ (Neat) $\mathrm{cm}^{-1}: 3270(\mathrm{NH}), 1681$ $(\mathrm{C}=\mathrm{O}) ;{ }^{1} \mathrm{H}$ NMR $\left(\mathrm{CDCl}_{3}, 400 \mathrm{MHz}\right): \delta 2.13(2 \mathrm{H}, \mathrm{dd}, J=7.0,7.0 \mathrm{~Hz}, \mathrm{H}-4), 2.31$ $(2 \mathrm{H}, \mathrm{d}, J=7.0 \mathrm{~Hz}, \mathrm{H}-3), 3.40(2 \mathrm{H}, \mathrm{t}, J=7.0, \mathrm{~Hz}, \mathrm{H}-5), 6.04(1 \mathrm{H}, \mathrm{br} \mathrm{s}, \mathrm{NH})$; ${ }^{13} \mathrm{C} \mathrm{NMR}\left(\mathrm{CDCl}_{3}, 100 \mathrm{MHz}\right): \delta 21.0$ (C-4), 29.9 (C-3), 42.2 (C-5), 179.5 (C-2); EI-MS $m / z$ (rel. int): 85 [M] $]^{+}(12)$. HREIMS $m / z 85.0528$ (calcd for $\mathrm{C}_{4} \mathrm{H}_{7} \mathrm{NO}$, 85.0525).

2-(2-amino-3-methyl-butyrylamino)-3-(4-hydroxy-phenyl)-propionic acid (2): White powder; $[\alpha]_{\mathrm{D}}^{25}: \pm 0^{\circ}(c 0.09, \mathrm{MeOH}) ; \mathrm{UV}(\mathrm{MeOH}) \lambda \quad(\log$ ع): $275(3.72) \mathrm{nm}$. IR $v_{\text {max }}$ (Neat) $\mathrm{cm}^{-1}: 3488(\mathrm{OH}), 1680(\mathrm{C}=\mathrm{O}), 1620,1580$ (benzene ring) $\mathrm{cm}^{-1} ;{ }^{1} \mathrm{H}$ NMR (DMSO-d, $400 \mathrm{MHz}$ ): $\delta 0.50,0.82$ (each $3 \mathrm{H}$, t, $\left.J=6.8 \mathrm{~Hz}, \mathrm{CH}_{3}-5^{\prime}, 4^{\prime}\right), 1.65\left(1 \mathrm{H}, \mathrm{m}, \mathrm{H}-3^{\prime}\right), 2.94(1 \mathrm{H}, \mathrm{dd}, J=14.0,4.8$, $\mathrm{Hz}, \mathrm{H}-3), 3.14(1 \mathrm{H}, \mathrm{dd}, J=14.0,5.2, \mathrm{~Hz}, \mathrm{H}-3), 3.63(1 \mathrm{H}, \mathrm{dd}, J=4.8,1.6$ $\left.\mathrm{Hz}, \mathrm{H}-2^{\prime}\right), 4.24(1 \mathrm{H}, \mathrm{dd}, J=5.2,4.8 \mathrm{~Hz}, \mathrm{H}-2), 6.71,7.04$ (each $2 \mathrm{H}, \mathrm{d}, J=8.8$ $\mathrm{Hz}, \mathrm{H}-6,8$ and $\mathrm{H}-5,9), 8.12$ (1H, br s, NH-1, $\mathrm{D}_{2} \mathrm{O}$ exchangeable); EI-MS $m / z$ (rel. int): $280\left[\mathrm{M}^{+}(8), 156\right.$ (40), 107 (60); HRESIMS $m / z 303.1321$ (calcd for $\left.\mathrm{C}_{14} \mathrm{H}_{20} \mathrm{~N}_{2} \mathrm{O}_{4} \mathrm{Na}, 303.1320\right)$.

\section{Antimicrobial activity assays}

Test microorganisms. The in vitro antimicrobial activity of compounds 1-11 were tested against a panel of laboratory control strains belonging to the Bioresource Collection and Research Center (BCRC), Hsinchu, Taiwan: Gram-positive: Staphylococcus aureus subsp. aureus (BCRC 10451), and Bacillus subtilis subsp. subtilis (BCRC-10255), Gram-negative: Pseudomonas aeruginosa (BCRC-11633), Klebsiella pneumoniae subsp. pneumoniae (BCRC16082) and Escherichia coli (BCRC-11634), and fungal organisms Aspergillus niger (BCRC-31512), Penicillium italicum (BCRC-30567), Candida albicans (BCRC-21538), and Saccharomyces cerevisiae (BCRC-20822). 
Evaluation of antimicrobial activity. Disc diffusion method according to the NCCLS ${ }^{5}$ was employed for determination of antimicrobial activity of the compounds. Briefly, a suspension of the tested microorganisms $(0.1 \mathrm{~mL}$ of $10^{8}$ cells per $\mathrm{mL}$ ) was spread on the solid media plates. The following nutritive media were used: Antibiotic Medium 1 (Difco Laboratories, Detroit, Michigan, USA) for growing Gram-positive and Gram-negative bacteria and Tripton soy agar (TSA; Torlak, Belgrade) for Aspergillus niger, Penicillium italicum, Candida albicans, and Saccharomyces cerevisiae. Nutritive media were prepared according to the instructions of the manufacturer. All agar plates were prepared in $90 \mathrm{~mm}$ Petri dishes with $22 \mathrm{~mL}$ of agar giving a final depth of $4 \mathrm{~mm}$. Sterile filter paper disks ( $8 \mathrm{~mm}$ in diameter; Advantec, Tokyo, Japan) were impregnated with $50 \mu \mathrm{L}$ of the sample solution in dimethylsulphoxide (DMSO), $1 \mathrm{mg} / 1 \mathrm{~mL}$ of DMSO (all solutions were filter-sterilized using a $0.45 \mathrm{~mm}$ membrane filter) and placed on inoculated plates. These plates, after standing at $4{ }^{\circ} \mathrm{C}$ for 2 hours, were incubated at $37{ }^{\circ} \mathrm{C}$ for 24 hours for bacteria and at $30^{\circ} \mathrm{C}$ for 48 hours for the fungi. Standard disk of tetracycline was used as a positive control, while the disk imbued with $50 \mu \mathrm{L}$ of pure DMSO as a negative control. The diameters of the inhibition zones were measured in millimeters and means of a slide caliper. Each test was performed in triplicate and repeated three times and results analyzed for statistical significance. Mean values were recorded.

\section{RESULTS AND DISCUSSION}

The EtOAc extract from the fermentation broth of FIRDI 001 was separated by a combination of silica gel, Sephadex LH-20, and prep. TLC and 11 compounds were identified. The structures of these compounds were elucidated by 1D and 2D NMR spectra and comparison with literature data. Iodinin (3) was found the major metabolite of FIRDI 001, and compounds $\mathbf{1}$ and $\mathbf{2}$ were isolated for the first time from natural source, though it has been synthesized ${ }^{6,7}$.

Pyrroline-2-one (1) was obtained as colorless oil. No UV absorption showed the structure has no conjugated chromosphere. The IR absorptions at 3270, and $1681 \mathrm{~cm}^{-1}$ provided evidence for amide amino and amide carbonyl groups. The ${ }^{1} \mathrm{H}$ NMR spectrum of $\mathbf{3}$ showed a set of mutually coupled methylene H-atoms at $\delta 2.13(2 \mathrm{H}, \mathrm{dd}, J=7.0,7.0 \mathrm{~Hz}, \mathrm{H}-4)$, and $2.31(2 \mathrm{H}, \mathrm{d}, J=7.0 \mathrm{~Hz}, \mathrm{H}-3)$, along with a nitrogen-bearing methylene proton at $3.40(2 \mathrm{H}, \mathrm{t}, J=7.0, \mathrm{~Hz}, \mathrm{H}-5)$, together with $\mathrm{COSY}$ correlations (figure 1), established a fragment $-\mathrm{CH}_{2}-\mathrm{CH}_{2}-$ $\mathrm{CH}_{2}-$. In combination with the HMBC correlations from $\mathrm{H}-3,4$ and 5 to $\mathrm{C}-2$, this led to the establishment of the structure as shown. From the above data, compound $\mathbf{1}$ was characterized as pyrroline-2-one, and the structure assigned to pyrroline-2-one (1) as shown in figure 1, which was further confirmed by COSY, NOESY and HMBC (figure 1) experiments. Compound 1 was first isolated from natural source, though it has been synthesized ${ }^{6}$.

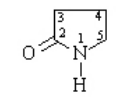

pynolidin-2-one (1)<smiles>Cc1c[nH]c(=O)[nH]c1=O</smiles>

thymine (4)<smiles></smiles>

uracil (7)<smiles>CC1c2ccc(Br)cc2OC(=O)C1NC(=O)C(N)C(C)(C)C(C)C</smiles>
2-(2-amino-3-methyl-butyrylamino)-3-
(4hydroxy-phenyl)-propionic ac id (2)

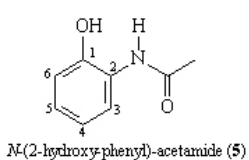

N(2-hydroxyphheny)-acetamide (5)<smiles>O=C(O)c1cccnc1</smiles>

ricotinic acid (8)

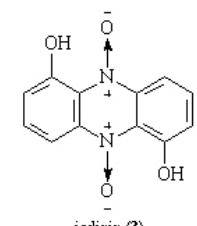

$\operatorname{iodirin}(3)$

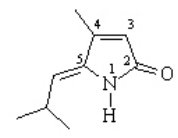

(2)-pulchellalactam (6)

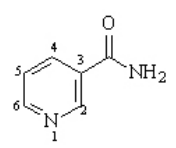

ricotiamide (9)
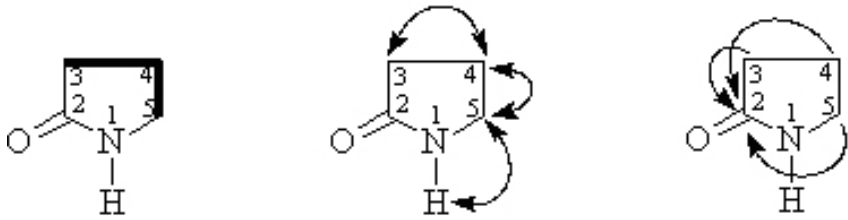

Figure. 1. Significant COSY, NOESY and HMBC correlations of $\mathbf{1}$

2-(2-Amino-3-methyl-butyrylamino)-3-(4-hydroxy-phenyl)-propionic acid (2) was obtained as colorless needles. Its molecular formula was established as $\mathrm{C}_{14} \mathrm{H}_{20} \mathrm{~N}_{2} \mathrm{O}$ by EIMS ([M $\left.]^{+}, m / z 280\right)$ and HRESIMS $(m / z$ 303.1321). The UV spectrum showed absorption maxima at $276 \mathrm{~nm}$, and suggested 2 with a benzenoid moiety. The IR spectrum of $\mathbf{2}$ showed characteristic absorption for amide amino (overlapped with hydroxyl), $\mathrm{C}=\mathrm{O}$, and benzene ring at 3488 , 1680,1620 and $1580 \mathrm{~cm}^{-1}$, respectively. The ${ }^{1} \mathrm{H}$ NMR spectrum also showed AB doublets with $J=8.8 \mathrm{~Hz}$ in the aromatic region suggesting the presence of a 1,4-disubstituted benzene ring. The signals appeared at $\delta 6.71(2 \mathrm{H}, \mathrm{d}, J=$ $8.8 \mathrm{~Hz})$ and $7.04(2 \mathrm{H}, \mathrm{d}, J=8.8 \mathrm{~Hz})$ corresponding to $\mathrm{H}-6, \mathrm{H}-8, \mathrm{H}-5$, and H-9, respectively. A 2-(2-amino-3-methyl-butyrylamino)-propionic acid group $[\delta$ $0.50,0.82$ (each $\left.3 \mathrm{H}, \mathrm{t}, J=6.8 \mathrm{~Hz}, \mathrm{CH}_{3}-5^{\prime}, 4^{\prime}\right), 1.65$ (1H, m, H-3'), 2.94 (1H, dd, $J=14.0,4.8, \mathrm{~Hz}, \mathrm{H}-3), 3.14(1 \mathrm{H}, \mathrm{dd}, J=14.0,5.2, \mathrm{~Hz}, \mathrm{H}-3), 3.63(1 \mathrm{H}$, dd, $J=4.8,1.6 \mathrm{~Hz}, \mathrm{H}-2$ '), 4.24 (1H, dd, $J=5.2,4.8 \mathrm{~Hz}, \mathrm{H}-2), 8.12$ (1H, br s, $\mathrm{NH}-1, \mathrm{D}_{2} \mathrm{O}$ exchangeable)] was observed and suggested to be located at $\mathrm{C}-4$ by the NOESY correlations between $\mathrm{H}-3 / \mathrm{H}-5,9$ (Fig. 2). The presence of an $\mathrm{OH}$ group as para-substituent was clearly demonstrated by the hydroxyl absorption band at 3488 in the IR spectrum. The correlations of H-5/H-6; H-8/ H-9; H-2/H-3; H-2'/H-5', 4'; and H-4'/H-5' were also observed in the NOESY spectrum (figure 2) and further support the position of aromatic substitution. From the above data, compound 2 was characterized as 2-(2-amino-3-methylbutyrylamino)-3-(4-hydroxy-phenyl)-propionic acid, and its structure was illustrated as 2, which was further confirmed by COSY and NOESY (figure 2) experiments. Compound $\mathbf{2}$ was first isolated from a natural source, though it has since been synthesized ${ }^{7}$.<smiles>CC(C)[C@H](N)C(=O)N[C@@H](Cc1ccc(O)cc1)C(=O)O</smiles>

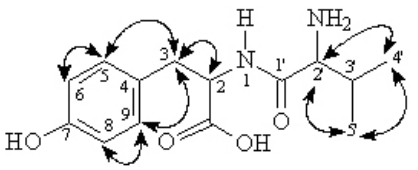

Figure. 2. Significant COSY, and NOESY correlations of 2.

The other known isolates identified in this study including nine alkaloids, iodinin $(\mathbf{3})^{8}$, thymine $(\mathbf{4})^{9}, \quad N$-(2-hydroxy-phenyl)-acetamide $(\mathbf{5})^{10}, \quad(Z)$ pulchellalactam $(6)^{11}$, uracil $(7)^{12}$, nicotinic acid $(8)^{13}$, nicotiamide $(\mathbf{9})^{14}$, $p$-nitrophenol $(\mathbf{1 0})^{15}$, indole 3-carboxylic acid $(\mathbf{1 1})^{16}$, were confirmed by comparison of physical and spectroscopic data (UV, IR, ${ }^{1} \mathrm{H}-\mathrm{NMR},[\alpha]_{\mathrm{D}}$, and mass spectroscopic data) to corresponding authentic samples or literature values. The identified eleven compounds were first report in the genus Acrocarpospora.

The antimicrobial activities of the isolates from FIRDI 001 culture broth were tested against bacteria such as Staphylococcus aureus subsp. aureus (BCRC 10451), Bacillus subtilis subsp. subtilis (BCRC-10255), Pseudomonas aeruginosa (BCRC-11633), Klebsiella pneumoniae subsp. pneumoniae (BCRC-16082) and Escherichia coli (BCRC-11634), and the following fungi: Aspergillus niger (BCRC-31512), Penicillium italicum (BCRC-30567), Candida albicans (BCRC-21538), and Saccharomyces cerevisiae (BCRC20822). The antimicrobial data are shown in Table 1 and clinically used antimicrobial agent, tetracycline, was used as positive control. Our results indicated metabolites $\mathbf{2 , 3}$ and $\mathbf{1 0}$ present antimicrobial activities, and which were absent in the other compounds. From the results of the antimicrobial tests, the following conclusions can be drawn regarding these isolates: (a) Among the alkaloids, only iodinin (3) as major metabolite, showed moderate antibacterial and antifungal activities. Compound $\mathbf{3}$ indicated the inhibition zones of 20 mm against $S$. aureus, $B$. subtilis, and $P$. aeruginosa, and showed moderate to strong antifungal activities with inhibition zones of 13, 23, 19 and $17 \mathrm{~mm}$ against $A$. niger, $P$. italicum, $C$. albicans, and $S$. cerevisiae, respectively. (b) The alkaloid, 2-(2-amino-3-methyl-butyrylamino)-3-(4-hydroxy-phenyl)propionic acid (2) exhibited weak to moderate antibacterial and antifungal activities against all tested strains. (c) C. albicans, and S. cerevisiae, the yeast 
we tested, were resistant to most of the isolated metabolites $(\mathbf{1}, \mathbf{2}, \mathbf{4}-\mathbf{1 1})$; however, compound $\mathbf{3}$ showed considerable activity against $C$. albicans, and $S$. cerevisiae. (d) Another known compound, $p$-nitrophenol (10) also displayed moderate antibacterial and antifungal activities against $S$. aureus, $B$. subtilis, $P$. aeruginosa, E. coli, A. niger, and P. italicum.

Table 1.- Antimicrobial activity of compounds isolated from the whole broth of Acrocarpospora sp. FIRDI 001 (diameter of the zone of growth inhibition, bactericidal or fungicidal zone in $\mathrm{mm}$, including the diameter of disc, $8 \mathrm{~mm}$ )

\begin{tabular}{|c|c|c|c|c|c|c|c|c|c|c|c|c|}
\hline $\begin{array}{c}\text { Test } \\
\text { microorganism }\end{array}$ & \multicolumn{70}{|c|}{ Isolated compounds } \\
\hline & $\mathbf{1}$ & $\mathbf{2}$ & $\mathbf{3}$ & $\mathbf{4}$ & $\mathbf{5}$ & $\mathbf{6}$ & $\mathbf{7}$ & $\mathbf{8}$ & $\mathbf{9}$ & $\mathbf{1 0}$ & $\mathbf{1 1}$ & $\mathbf{S T D}$ \\
\hline $\begin{array}{c}\text { S. aureus subsp. } \\
\text { aureus }\end{array}$ & - & 24 & 20 & - & - & - & - & - & - & 22 & - & 25 \\
\hline $\begin{array}{c}\text { B. subtilis subsp. } \\
\text { subtilis }\end{array}$ & - & 20 & 20 & - & - & - & - & - & - & 22 & - & 24 \\
\hline $\begin{array}{c}\text { P. aeruginosa } \\
\text { E. coli }\end{array}$ & - & 22 & 20 & - & - & - & - & - & - & 22 & - & 24 \\
\hline A. niger & - & 12 & 13 & - & - & - & - & - & - & 19 & - & 18 \\
\hline P. italicum & - & 13 & 23 & - & - & - & - & - & - & 20 & - & 18 \\
\hline C. albicans & - & - & 19 & - & - & - & - & - & - & - & - & 16 \\
\hline S. cerevisiae & - & - & 17 & - & - & - & - & - & - & - & - & 16 \\
\hline
\end{tabular}

Inhibition zone diameter $(\mathrm{mm}) ;-=$ no Inhibition zone; Positive control (STD): Tetracycline

In summary, some secondary metabolites including the major metabolite, iodinin, displayed antimicrobial activities were found in the strain FIRDI 001, the putative novel species of Acrocarpospora. Two compounds (1 and $\mathbf{2}$ ) produced by strain FIRDI 001 were first report found from natural source and their bioactivities would be further investigated.

\section{ACKNOWLEDGEMENTS}

We appreciate the financial support by the Ministry of Economic Affairs, Taiwan, ROC

\section{REFERENCES}

1. W. Fenical, J. Nat. Prod., 93, 1673, (1993).

2. X. C. Cheng, P. R. Jensen, W. Fenical, J. Nat. Prod., 62, 608, (1999).

3. T. Tamura, S. Suzuki, K. Hatano, Int. J. Syst. Bacteriol, 50, 1163, (2000).

4. M. Hayakawa, H. Nonomura, J. Ferment. Technol., 65, 501, (1987).

5. NCCLS (National Committee for Clinical Laboratory Standards) Performance standards for antimicrobial disk susceptibility testing; 6th International Supplement, Wayne Pa 1997, p M2-A6.

6. C. R. Ganellin, P. B. Bishop, R. B. Bambal, M. T. Chan, J. K. Law, B. Marabout, P. M. Luthra, N. J. Moore, O. Peschgard, P. Bourgeat, C. Rose, F. Vargas, J. C. Schwartz, J. Med. Chem., 43, 664, (2000).

7. T. Pathak, N. F. Thamos, M. Akhtar, D. Gani, Tetrahedron, 46, 1733, (1990)

8. H. Tsujibo, T. Sato, M. Inui, H. Yamamoto, Y. Inamori, Agric. Biol. Chem. 52, 301, (1988).

9. E. C. Wang, H. Y. Chen, C. C. Tzeng, J. Chin. Chem. Soc., 40, 73, (1993).

10. M. Zikmundová, K. Drandarov, M. Hesse, C. Werner, Zeitschrift für Naturforschung, 57, 660, (2002).

11. J. S. Bryans, N. E. A. Chessum, N. Huther, A. F. Parsons, F. Ghelfi, Tetrahedron, 59, 6221, (2003).

12. T. Koyama, T. Morikita, Chem. Pharm. Bull, 51, 32, (2003).

13. C. Y. Chen, F. R. Chang, C. M. Teng, Y. C. Wu, J. Chin. Chem. Soc., 46, 77, (1999).

14. N. Yamashita, K. Sakata, H. Ina, K. Ina, Agric. Biol. Chem. 53, 3351, (1989).

15. G. Lin, C. Y. Lai, W. C. Laio, P. S. Laio, C. H. Chan, J. Chin. Chem. Soc., 50, 1259, (2003).

16. H. Kai, M. Baba, T. Okuyama, Chem. Pharm. Bull., 55, 133, (2007). 